\title{
CARBON ACCOUNTING, DISCLOSURE AND MEASUREMENT: A SYSTEMATIC LITERATURE REVIEW
}

\author{
Erwin Saraswati \\ Economic and Business Faculty \\ Brawijaya University
}

\begin{abstract}
Purpose - This research aims to support Sustainable Development Goals specifically to reduce carbon emission.

Design/methodology/approach - Systematical literature review was used as a research method, evaluated and analyzed as much as 17 articles. Findings - The result indicate that mitigation is more preferable than adaptation in case of carbon emission accounting definition. Stakeholders were involved to applied carbon disclosure which support the stakeholder theory, while measurement of carbon emission found that carbon-footprint approach is more widely used by organizations.

Practical Implications - Environmental field become one of the SDG's (Sustainable Development Goals) objectiveas it is related to the climate change caused by carbon emission that significantly increase from 1990's. Originality/value - This research delivers concept, definition, practice, and measurement of gas emission based on previous research result (by several researchers/research paper) in various countries.

Keywords - Climate change, carbon accounting, adaptationandmitigation, carbon-footprint approach.
\end{abstract}

\section{INTRODUCTION}

Recently, climate change become a global issue and being concern in the most countries around the world. United Nations Framework Convention on Climate Change (UNFCCC) explain that human activities, both direct and indirect, are a factor that lead to the climate change which shifted the world athmosphere composition (Intergovernmental Panel on 
Climate Change in www.ipcc.ch). Greenhouse gas was significantly increase since 1990's (see Figure 1).

FIGURE 1

ANNUAL $\mathrm{CO}_{2}$ EMMISIONS BY WORLD REGION

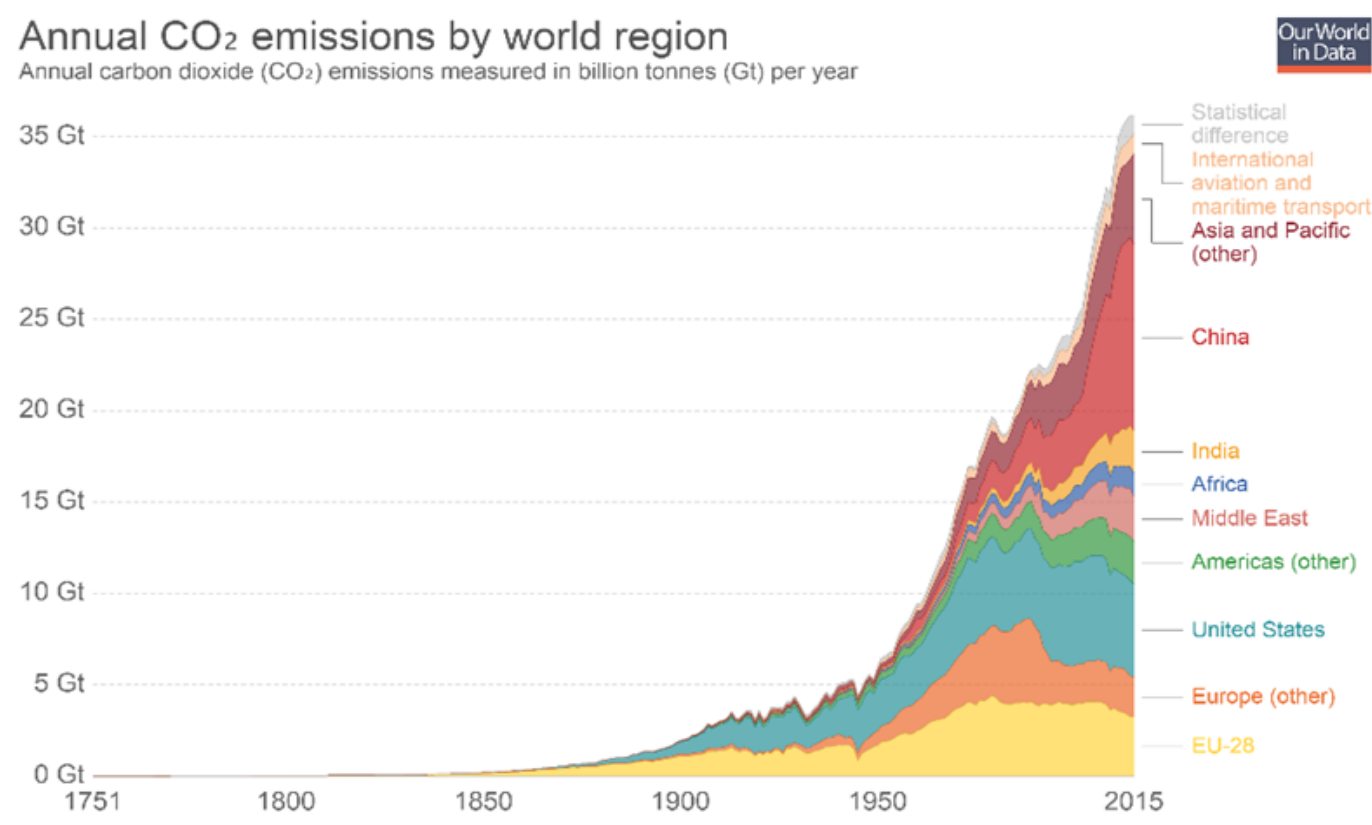

Source: www.ourworldindata.org

The increasing of gas emission induce United Nations create Intergovernmental Panel on Climate Change (IPCC) and published Kyoto Protocol in international conference as an instrument to stabilize Green House Gas (GHG) concentration that had been ratified by at least 55 members. Kyoto Protocol is implemented in three mechanisms, namely Emission Trading (ET), Clean Development Mechanism (CDM), and Joint Implementation (JI). Renewal of 1997 Kyoto Protocol, agreed at the $21^{\text {st }}$ Conference of Parties (COP) with the Paris Agreem015 which shows the commitment of the countries to maintain increasing earth temperature 
below $2{ }^{\circ} \mathrm{C}$. Production of gas emission in Indonesia absolutely reaches $1.2 \%$ of total world emissions which put Indonesia in the $21^{\text {st }}$ position worldwide.

In Indonesia, carbon emission disclosure is still classified as voluntary because Indonesia is a Non-Annex group, means developing country that is not required to reduce carbon emissions, but reports on emissions status. The importance of disclosing carbon emission is expected to push the companies to be more transparent about environmental information, so that stakeholders can monitor the extent to which companies care about climate change (Ernst \& Young, 2011). Company management will be pressured to evaluate climate change concerns, including company policies. Carbon report is a company policy that can maintain its legitimacy (Pellegrino \&Lodhia, 2012), which shows that companies operate according to social, legal and community norms.

Unfortunately, carbon reports are still voluntary in some countries, so they do not yet have standardized standards and cause differences in disclosure. Another consideration is the difficulty of measuring carbon emissions. Some researchers even give different definitions to carbon accounting. This study aims to provide the concept of carbon accounting in the sense of integrating aspects of climate change into accounting and measurement through mitigation and adaptation. This study refers to the research of Stechemesser and Guenther (2012), who found several scales 
of understanding of carbon accounting, and Ascui and Lovell (2011), about five framing carbon accounting.

The contribution of this research is to provide benefits for companies, governments and policy makers related to the recording, measurement and reporting of carbon emissions. The results of the carbon accounting concept can support one of SDG's objectives, in environmental aspects.

\section{LITERATURE REVIEW}

\section{Carbon Accounting}

The definition of carbon accounting based on available evidence is difficult to understand and problematic (Ascui and Lovell, 2011). Therefore, the term carbon itself gives a different meaning, scientists understand strictly with something that is carbon (elemental carbon), or more popular greenhouse gases or $\mathrm{CO} 2$. When combined with accounting into different frames, it is possible to give different meanings.

Carbon accounting is recognizing, monetary and non-monetary evaluation and monitoring of greenhouse gases at each level of the value chain and recognizing, evaluating and monitoring the impact of gas emission on the ecosystem of the carbon cycle (Stechemesser and Guenther, 2012). Carbon accounting can occur at several scales (see figure 2). First, carbon accounting at the National level is further developed by the Kyoto protocol (Gibassier, 2015). Second, at the organizational level, carbon accounting consists of three types, which are upstream scope 3 emissions, scope 1 and 2 emissions and downstream scope 3 emissions. Finally, at the product level, directly related to the production process. Some companies 
FIGURE 2

RELATIONSHIP BETWEEN CORPORATION (ORGANIZATION) AND PRODUCT

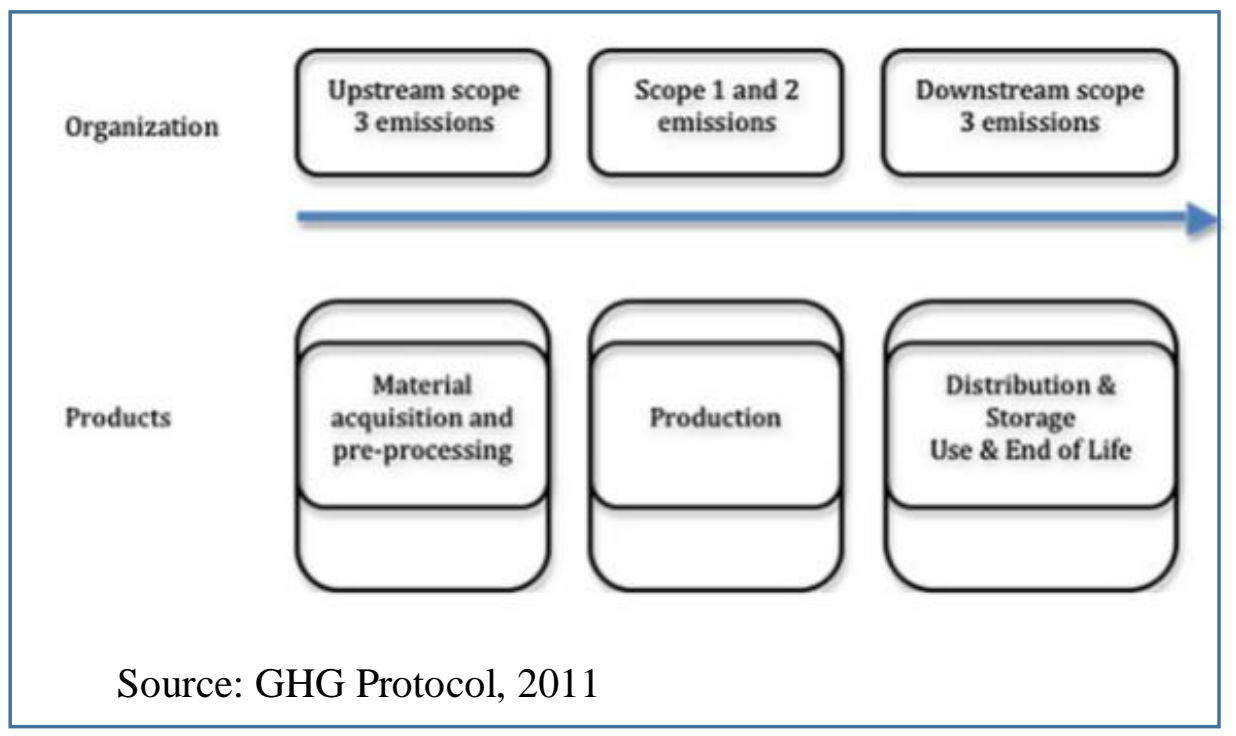

As explained earlier in relation to the coverage of gas emissions (also called operational boundaries), scope 1 including gas emission can be directly controlled by the organization. This boundary is a territorybased approach. Scope 2 includes indirect gas emissions related to electricity production. Companies can only reduce by investing in sophisticated technology, while scope 3 emissions are not directly as a result of a company's operations. This can be controlled by other companies.

The initiation of carbon accounting was launched at different levels, from the National to local and corporate levels, but there was no coordination between those two. There are two categories of calculation approaches (Brohe, 2017). First, the territory-based approach, which 
analyzes GHG emissions and is in principle useful for producing national inventory reports; second, the carbon footprint approach, which calculates the carbon impact of an organization, an area or even a product through a lifecycle.

In implementing the measurement of climate change impact, companies will consider mitigation strategies, adaptation or a combination of both (Kolk and Pinkse, 2005; Kolk et al., 2008). This will consider the costs and benefits in the area of carbon accounting in an organization. In the adaptation measurement strategy, companies have predominated corporate practice (CDP, 2012). If a company takes a perspective, there are three different dimensions, namely climate knowledge absorption, climate related operational flexibility and strategic climate integration (Busch, 2010).

Another alternative strategy, that is mitigation, is essentially an organization trying to avoid gas emissions (GHG). The focus of implementation and operations relates to organizational structure and processes (Schaltegger et al., 2015).

\section{RESEARCH METHOD}

This study refers to the research method used by Stechemesser and Guenther (2012), using a systematic literature review. The purpose of a systematic literature review is to synthesize research and comprehensively to get certain questions, by organizing, transparent and replicative procedures for each stage of the process (Littel, 2008). In this case, Vol. 28, No. 2 August 2020

(C) Centre for Indonesian Accounting and Management Research Postgraduate Program, Brawijaya University 
researchers focus on the definition, application and measurement of carbon accounting.

Stechemesser and Guenther (2012) used four stages for a systematic review according to what Fink (2010) did and the basic structure by Tranfield et al. (2003). The first stage, selecting research questions through an article database. The next step determines the relevant article criteria. The third stage, applying and developing methods of review criteria. The last stage, synthesizing and finding research results.

\section{Unit Analysis}

This study uses an analysis of article units published from 20002019, from Scopus journals, indexed journals and Indonesian journal Sinta 2 (if any). Search for articles using keywords, carbon accounting, carbon footprint, climate change, carbon and GHG emission.

\section{DISCUSSION}

The discussion uses four steps:

\section{Step 1 and 2 (Mapping articles and searches comprehensively)}

The discussion is based on research journals that have been collected by researchers. Search for articles by keywords carbon accounting, carbon footprint, climate change, carbon and GHG emission. Search through google scholar and obtained as many as 17 research journals published from 2009 to 2019. Furthermore, researchers classified the journals into two categories, namely journals that are relevant to the theme of Carbon 
Accounting and irrelevant journals. The results of the classification of the journal are set out in Table 1.

TABLE 1.

RELEVANCE OF JOURNALS RESEARCHED WITH RESEARCH THEMES

\begin{tabular}{|c|l|c|}
\hline No & \multicolumn{1}{|c|}{ Relevance } & Journal Amount \\
\hline 1 & Searched from google scholar & 88 \\
\hline 2 & $\begin{array}{l}\text { Relevance with Carbon Accounting } \\
\text { theme }\end{array}$ & 17 \\
\hline 3 & $\begin{array}{l}\text { Irrelevant with Carbon Accounting } \\
\text { theme }\end{array}$ & 4 \\
\hline & \multicolumn{1}{|c|}{ Total analyzed } & $\mathbf{1 3}$ \\
\hline
\end{tabular}

Source: Data processed (2019)

Thus, in this study analyzing as many as 17 journals that are relevant to the research question.

\section{Step 3 (Quality Valuation)}

After classification according to Table 1 above, the researcher made further groupings for journals that were considered relevant to the themes discussed. Relevant journals are grouped into three main discussion groups: journals that discuss the definition of carbon accounting, journals that discuss the application of carbon accounting and journals that discuss the measurement of carbon accounting. The results of the grouping can be seen in Table 2.

The relevant groupings of journals consist of two journals for the definition of carbon accounting, seven journals for their application, while the measurement of carbon accounting is in 4 journals. Next will be discussed for each journal result.

Vol. 28, No. 2 August 2020

(C) Centre for Indonesian Accounting and Management Research Postgraduate Program, Brawijaya University 
TABLE 2.

JOURNAL GROUPING BASED ON RESEARCH FOCUS

\begin{tabular}{|c|l|c|}
\hline No & \multicolumn{1}{|c|}{ Research Focus } & Journal Amount \\
\hline 1 & Carbon Accounting definition & 2 journals \\
\hline 2 & Carbon Accounting application & 7 journals \\
\hline 3 & Carbon Accounting measurement & 4 journals \\
\hline & Total & 13 Journals \\
\hline
\end{tabular}

Source: Data processed (2019)

\section{Step 4 (Data Extraction)}

The results of data extraction are summarized in table 3 . The extraction process has been carried out by the procedure of perusing the articles one by one that is obtained, summarizes and the final stage will be pressured (step 5). Based on the data extraction results there are two journals from Accounting, Auditing and Accountability Journal, and Corporate Carbon and Climate Accounting, which explain the definition of carbon emissions accounting.

Discussion of carbon emission disclosure divide into seven journals (details include in Table 3). As well as journal definition and research name of carbon emission measurement, was also provided in Table 3.The most journals in this research were Accounting, Auditing, and Accountability Journals, with four articles, while others varied. Since researchers obtained only few journals for 2019, the results can not be present in this research.

\section{TABLE 3.}

\section{RESULTS OF DATA EXTRACTION}

Vol. 28, No. 2 August 2020

(C) Centre for Indonesian Accounting and Management Research Postgraduate Program, Brawijaya University 


\begin{tabular}{|c|c|c|c|}
\hline Topic & Author & Year & Journal \\
\hline \multirow{2}{*}{$\begin{array}{l}\text { Carbon } \\
\text { Accounting } \\
\text { Definition }\end{array}$} & $\begin{array}{l}\text { Fransisco Ascui, } \\
\text { Heather Lovell }\end{array}$ & 2011 & $\begin{array}{l}\text { Accounting, Auditing } \\
\text { and Accountability } \\
\text { Journal }\end{array}$ \\
\hline & $\begin{array}{l}\text { Dimitar Zvezdov, } \\
\text { Stefan Schaltegger }\end{array}$ & 2015 & $\begin{array}{l}\text { Corporate Carbon and } \\
\text { Climate Accounting }\end{array}$ \\
\hline \multirow{7}{*}{$\begin{array}{l}\text { Application } \\
\text { of Carbon } \\
\text { Emission } \\
\text { Disclosures }\end{array}$} & Sue Hrasky & 2011 & $\begin{array}{l}\text { Accounting, Auditing } \\
\text { and Accountability } \\
\text { Journal }\end{array}$ \\
\hline & $\begin{array}{l}\text { Jayanthi Kumarasiri, } \\
\text { Christine Jubb }\end{array}$ & 2016 & $\begin{array}{l}\text { Accounting Research } \\
\text { Journal }\end{array}$ \\
\hline & $\begin{array}{l}\text { Christian Blanco, } \\
\text { Felipe Caro, Charles } \\
\text { J. Corbett }\end{array}$ & 2017 & Business Horizons \\
\hline & $\begin{array}{l}\text { Heather Lovell, } \\
\text { Donald MacKenzie }\end{array}$ & 2012 & Antipode \\
\hline & Tiago Melo & 2012 & $\begin{array}{l}\text { Social Responsibility } \\
\text { Journal }\end{array}$ \\
\hline & $\begin{array}{l}\text { Bo Bae Choi, } \\
\text { Doowon Lee, Jim } \\
\text { Psaros }\end{array}$ & 2013 & $\begin{array}{l}\text { Pacific Accounting } \\
\text { Review }\end{array}$ \\
\hline & $\begin{array}{l}\text { Michaela Rankin, } \\
\text { Carolyn Windsor, } \\
\text { Dina Wahyuni }\end{array}$ & 2011 & $\begin{array}{l}\text { Accounting, Auditing } \\
\text { and Accountability } \\
\text { Journal }\end{array}$ \\
\hline \multirow{4}{*}{$\begin{array}{c}\text { Carbon } \\
\text { Emission } \\
\text { Measurement }\end{array}$} & $\begin{array}{l}\text { Matthew Haigh, } \\
\text { Matthew A. Shapiro }\end{array}$ & 2011 & $\begin{array}{l}\text { Accounting, Auditing } \\
\text { and Accountability } \\
\text { Journal }\end{array}$ \\
\hline & Brantley Liddle & 2018 & Energy Economics \\
\hline & $\begin{array}{l}\text { Nabila Farhana } \\
\text { Jamaludin, Zarina } \\
\text { Ab Muis and } \\
\text { Haslenda Hashim } \\
\end{array}$ & 2019 & $\begin{array}{l}\text { Journal of Cleaner } \\
\text { Production }\end{array}$ \\
\hline & $\begin{array}{l}\text { Amani Maalouf, } \\
\text { Mutasem El-Fadel }\end{array}$ & 2018 & $\begin{array}{l}\text { Journal of Cleaner } \\
\text { Production }\end{array}$ \\
\hline
\end{tabular}

Source: Data Processed (2019) 


\section{Step 5 (Synthesis)}

This stage will discuss each of which can be synthesized according to the research questions.

\subsection{Carbon Accounting Definition}

Author found two journals explain all things related to the definition of carbon accounting, which are Ascui and Lovell (2011) and Zvezdov and Schaltengger (2015). Those researches clarify community reponses overcoming climate change problems such as carbon trading, national emission limitation commitments, measurement of carbon performance, and so on. Therefore, Acsui and Lovell (2011) divide concept of carbon accounting into five main frameworks: physical carbon accounting, political carbon accounting, market-enabling carbon accounting, financial carbon accounting, and social/environmental carbon accounting.

Furthermore, Zvezdov and Schaltengger (2015) conducted further research abount carbon accounting application through carbon management accounting. In that study, Zvezdov and Schaltengger (2015) define carbon management accounting as activity related to the goal of achieving efficient use of resources (considering the time of resources usage) and effective carbon reduction. Results of the research showed that most organizations carry out carbon accounting or carbon disclosure with legitimacy motivation oriented to profit and cost. This is contrary to the main concepts of sustainable development and corporate sustainability oriented towards sustainability in the future in making decisions related to 
carbon management, so as to improve the efficiency of carbon performance for organizations.

Based on thus two studies, can be concluded that definition of carbon accounting is a process of measuring carbon emission produced by an organization, providing efforts to reduce and report measurement's results to the stakeholder, in order to support sustainable development goals. In addition, carbon accounting is a real response to current global problem, climate change.

The discussion in the two articles above, support climate change measurement in mitigation aspect rather than adaptation. This is in line with the findings of Stechmesser and Guenter (2012) through an article review. The mitigation approach tends to minimize the costs of the global warming effect through reduction goals (Brohe, 2017). Therefore, for companies, mitigation approach is relatively easier to apply than adaptation.

\subsection{Carbon Accounting Application}

In this discussion, researcher found seven journals examine carbon accounting application in various aspects. First study was conducted by Hrasky (2011), discuss organization reporting carbon footprints disclosure. The fact, reporting of carbon footprints is consistents with legitimacy theory in gaining public recognition. Schuman (1995) stated that organizations want legitimacy to build assumption that an organization has acted based on the value and norm applied and do 
acceptable behavior. However, based on this research, the legitimacy sought by an organization can be distinguished according to the follow-up conducted on its carbon disclosure.

Organizations in a carbon intensive sector (produce a lot of carbon emission), such as mining, energy, and others, conduct carbon disclosure accompanied by several activities related to mitigation, as well as other reduction carbon emissions. This is inversely proportional with organizations in a less intensive sector (produce less carbon emissions), where carbon disclosure is only symbolic without being accompanied by follow-up on the disclosures. In this case, government's role is important to control organizations that gain legitimacy and organizations that make a symbolic disclosure.

This fact discovered by Hrasky (2011) has become an interesting issue for further investigation, due to a debate among elements of society regarding carbon disclosure. Some people assume that an organization carries out the reporting with motivation to gain legitimacy, but on the other hand there are some people who consider that the organization carries out carbon disclosure as a form of responsibility to external stakeholders such as the community, the environment, the government and so on.

Freeman (1984) argues that if an organization adhere to stakeholder theory, then itconsider value, morality, and good ethics in 
operating as a form of responsibility towards it's stakeholders. Thus, carbon disclosure can support the legitimacy theory and tend to be an act of symbolic activity. Conversely, if an organization discloses carbon emissions due to its responsibilities to stakeholders, the organization's actions are more substantive.

The government can encourage organizations to manage carbon emissions produced in the public interest by implementing regulations (Kumarasiri\&Jubb, 2016). Organizations apply carbon management accounting in managing their carbon emissions effectively to comply with applicable regulations, especially if there are monetary elements in the regulation (for example the application of carbon tax).

The application of effective carbon management accounting can provide financial benefits for organizations especially those engaged in carbon intensive sectors such as the avoidance of carbon taxes. Another case with organizations in the low carbon intensive sectors that apply carbon management accounting to show a good impression in responding to issues related to sustainability and environment. These different intentions from different sectors become obstacles in sustainable development, where different incentives from organizations make supporting activities for sustainable development not yet effectively implemented, so that government intervention is very crucial in solving this problem. 
Furthermore, Blanco, Caro and Corbett (2017) found that from the internal side of the organization implementing carbon disclosure. The results of the study show that organizations that implement carbon measurement and reporting benefit more diverse than expected. Blanco, Caro \& Corbett (2017) provide several recommendations for increasing credibility in the application of carbon reporting.

First recommendations from Blanco et al. (2017) is managers should be more aware of various biased decisions that can hinder investment in profitable emissions reduction opportunities. Second, participation in the reporting process provides beneficial benefits, even for organizations that decide not to disclose carbon. Third, management needs to address the reporting of greenhouse gas emissions not only to investors, but also to other stakeholders such as the community, employees, government and so on. Fourth, in the process of finding opportunities for reducing emissions, as well as reporting, management needs to consider that in the supply chain there are always opportunities that can not be exploited. Blanco et al. (2017) implisitly in line with the stakeholder theory which consider organization's stakeholder in every activity. Stakeholders will give additional value, both direct and indirect, if the organization carried out its activities by minimizing negative impacts for stakeholders.

Professional accounting organizations have an important role in implementing carbon accounting, accountants see the climate change as a serious problem for sustainability (Lovell and Mackenzie, 2012). 
Professional accounting organizations (for example FASB and IASB) respond to climate change using accounting approach by creating standards that can be widely used.

The standard used can be in the form of voluntary reporting of carbon emissions accompanied by restrictions on standard emissions (known as cap-and-trade and creating new markets for carbon trading) or in the form of imposition of carbon tax or pollution tax. The carbon tax or pollution tax is imposed on organizations that produce emissions that exceed specified standards and carry out activities that directly or indirectly damage the environment. This standard is not solely applied to give monetary value to carbon emissions, but about how greenhouse gas emissions produced by organizations can be reduced to support sustainable development.

Several journals found by researcher also discussed the factors that influence carbon disclosure activities for an organization. Melo (2012) found that corporate social performance was directly proportional to organizational culture and tenure management.

Melo (2012) also found that companies that pay attention to the social values of stakeholders show good social performance. In this case, the company's social performance consists of various aspects, one of which is carbon accounting. This of course proves that managers who realize that when an organization is accountable to all its stakeholders, there is a value that results from the relationship that has a positive impact on the Vol. 28, No. 2 August 2020

(C) Centre for Indonesian Accounting and Management Research Postgraduate Program, Brawijaya University 
company. Obviously, the existence of sufficient financial conditions and a long period of management work will increase the effectiveness of the company's social performance.

Choi, Lee and Psaros (2013) found several factors that can motivate an organization's voluntary disclosure of carbon emissions generated in its annual report. The first factor is the level of carbon emissions produced, so organizations in the carbon-intensive sector will make carbon emissions disclosures more broadly and comprehensively. The second factor is the size of the organization where organizations with large size and complex organizational levels will provide broader carbon emissions disclosure. The third factor is the quality of organizational governance because organizations with good governance are considered to be more responsible for all operational implications, especially to the environment, so that it will provide wider disclosure of carbon emissions. factor is the size of the organization where organizations with large size and complex organizational levels will provide broader carbon emissions disclosure. The third factor is the quality of organizational governance because organizations with good governance are considered to be more responsible for all operational implications, especially to the environment, so that it will provide wider disclosure of carbon emissions.

Things that can be identified significantly related to voluntary reporting of greenhouse gas emissions are organizations that doing voluntary reporting of greenhouse gas emissions and applying an environmental management system, have a good organizational governance system and conduct open reporting on the Carbon Disclosure Project (one of the non-profit 
organizations/NGOs that encourage reporting of carbon emissions in organizations) (Rankin, Windsor and Wahyuni, 2011).

The credibility of the emissions report is also strengthened by several things. The adoption of an ISO14001 certified environmental management system adds credibility to reporting. The larger the size of the organization will also provide wider and more credible reporting. In addition, pressure from institutional investors (institutional investors) who expect a good organizational carbon performance affects the credibility of the reporting organization.

Institutional Investors usually play an important role in the social activities of an organization including carbon accounting practices, because of the significant influence that comes from the large portion of its ownership in an organization. When Institutional Investors want an organization they have to improve their social performance, as well as carbon accounting practices, the organization will in theory do everything the investors want, especially those with a significant portion of ownership.

The implementation of carbon emissions disclosure is influenced by several factors, one of which is good governance. This will work effectively if the company has good environmental management (Choi, Lee and Psaros, 2013; Rankin, Windsor and Wahyuni, 2011).

\subsection{Carbon Accounting Measurement}

In this section, researcher discusses four relevant journals related to the main topic. Haigh and Shapiro (2011) mentions several references for measurement of carbon accounting. Those carbon emission measurement methods are shown on Table 4 below.

TABLE 4.

REFERENCES FOR CARBON ACCOUNTING MEASUREMENT

\begin{tabular}{|l|l|l|}
\hline \multicolumn{1}{|c|}{ Reference } & \multicolumn{1}{|c|}{ Measurement Intensity } & \multicolumn{1}{c|}{$\begin{array}{c}\text { Basis for } \\
\text { Calculation }\end{array}$} \\
\hline $\begin{array}{l}\text { Kyoto } \\
\text { Protocol }\end{array}$ & $\begin{array}{l}\text { Measurement intensity is not } \\
\text { explained }\end{array}$ & \\
\hline $\begin{array}{l}\text { Emission calculation is a function of } \\
\text { activity data, involving direct }\end{array}$ & Production activity \\
\hline
\end{tabular}

Vol. 28, No. 2 August 2020

(C) Centre for Indonesian Accounting and Management Research

Postgraduate Program, Brawijaya University 


\begin{tabular}{|c|c|c|}
\hline & $\begin{array}{l}\text { observations to emissions or } \\
\text { applications of emission factor }\end{array}$ & \\
\hline $\begin{array}{l}\text { EC Directives } \\
2007 / 589 \\
2003 / 87 \\
\text { Annex IV; } \\
96 / 61\end{array}$ & $\begin{array}{l}\text { - Measurement intensity is not } \\
\text { explained } \\
\text { - Emission calculation is a function of } \\
\text { activity data, emission factors and } \\
\text { oxidization factors }\end{array}$ & $\begin{array}{l}\text { Depends on } \\
\text { agreed-upon or } \\
\text { standardized } \\
\text { methods }\end{array}$ \\
\hline $\begin{array}{l}\text { Input-Output } \\
\text { Analysis }\end{array}$ & $\begin{array}{l}\text { - Measurement intensity is a function } \\
\text { of total resources consumed, cost of } \\
\text { consuming resources, activity data } \\
\text { and emission factor } \\
\text { - Need for structural modelling }\end{array}$ & $\begin{array}{l}\text { - Production } \\
\text { activity and cost } \\
\text { data } \\
\text { - Suitable for } \\
\text { analyzing limited } \\
\text { sectors }\end{array}$ \\
\hline $\begin{array}{l}\text { Structural } \\
\text { Decomposition } \\
\text { Analysis }\end{array}$ & $\begin{array}{l}\text { - Emission is a function of energy } \\
\text { intensity of emission, which depends } \\
\text { on activity rates (e.g. GDP, energy } \\
\text { used, population, production volume, } \\
\text { and operational income of an } \\
\text { organization) }\end{array}$ & $\begin{array}{l}\text { Rates of various } \\
\text { activities }\end{array}$ \\
\hline $\begin{array}{l}\text { British } \\
\text { Standard PAS } \\
2050\end{array}$ & $\begin{array}{l}\text { - Carbon footprint is a function of } \\
\text { activity data and emission factor } \\
\text { - Activity data is considered as raw } \\
\text { materials, while energy used is } \\
\text { related to product life cycle } \\
\text { - Uncertainty gives the need to } \\
\text { calculate probability density } \\
\text { - No need to report emission } \\
\text { calculation }\end{array}$ & Production activity \\
\hline $\begin{array}{l}\text { GHG Protocol } \\
\text { Standards }\end{array}$ & $\begin{array}{l}\text { - Emission volumes relate directly to } \\
\text { organizations and depend on } \\
\text { production quantity }\end{array}$ & $\begin{array}{l}\text { Production flow } \\
\text { rates }\end{array}$ \\
\hline
\end{tabular}

Source: Haigh \& Shapiro (2012, p. 113)

Although coming from different sectors, those six methods share the common goal to quantify carbon emissions, in order to improve decision 
making. Emission calculations by organizations will give positive impact towards organizational sustainability and sustainable development.

Moreover, Liddle (2018) compares carbon emission measurement; i.e. consumption-based carbon emissions and territory-based carbon emissions. Consumption-based carbon emissions are measured by calculating domestic fuel comsumption added with net imports (imports less exports). On the other hand, territory-based carbon emissions are measured by calculating carbon emissions produced in a country.

Both methods above can be used as quantitative measures in applying carbon accounting. However, the scope of those two methods depend on macroeconomic conditions; since the measurements use consumption and production rates in a country. Hence, the methods may not be useful in micro or organizational settings.

Jamaluddin, Muis and Hashmin (2019) combines two measurement methods for carbon footprint, e.g. carbon footprint accounting and palmoil sustainability index. It develops an integrated sustainability measurement for palm oil industry. This new method aims to reduce excessive data by introducing more comprehensive method, so decision making may be improved. However, this method has limitations since it can only be applied to palm-oil related industry and cannot be generalized to other industries. 
Comparative researches related to carbon emissions measurement are growing in numbers and in many regions (Maalouf and El-Fadel, 2018). That results in the high variability of the measurement methods, since the elements used in each method are varying; such as gases included, emission forms, measurement scope, and many others. This is because most methods are introduced in developed countries which have different parameters and focus.

Discussions in several carbon accounting journals show carbon measurements vary in practice. Although sharing the same goal to quantify emissions, differences remain exist due to variations in elements included in the calculation, and the focus of each measurement. The background and home country of the inventors also lead to differences in the measurements.

Looking at the variations of measurement methods, the researcher recommends that an international organization needs to be established as a regulatory body in carbon accounting. The organization can hopefully unify the different perspectives related to carbon accounting and issue an operating standard that can be universally applied by all organizations globally. The role of the government is still very crucial in supporting this organization, so that the standard can be applied in every country. This is also to address the bigger, universal issue of climate change. 
The research finds that definition of carbon emission accounting is currently in mitigation level, consistent with the findings of Stechmesser and Guenter (2012). Carbon accounting application that has been applied by organizations tend to direct towards carbon disclosure, holding stakeholder views instead of legitimacy. Whether management actions are categorized as substantive or symbolic need further research.

Lastly, article review on carbon emissions measurement finds that carbon measurement uses production basis or footprint approach. This is because consumption basis or territory-based approach basically use national production report (Kyoto Protocol uses this basis).

\section{CONCLUSION}

This research aims to define carbon accounting, as well as how to apply and measure carbon accounting by systematic literature review. Researcher tests and analyzes 17 articles found by entering the keywords of carbon accounting, carbon footprint, climate change, carbon and GHG emission. The literature search uses Google Scholar website for the observation periods of 2009-2019. The steps of systematic literature review follow Fink (2010) while the fundamental structure follows Tranfield et al. (2003) and Jesson, Matheson and Lacey (2011).

This research finds that: 
1. Definition of carbon emissions accounting uses mitigation approach instead of adaptation. Mitigation is relatively easier for organizations to apply.

2. Applications of carbon emissions disclosure tend to prioritize the needs of stakeholders, hence supporting stakeholder theory.

3. Carbon emissions measurement uses production basis or footprint approach. This is because consumption basis or territory-based approach basically use national production report (Kyoto Protocol uses this basis).

The result contributes to stakeholder theory which is widely used in organizational reporting on carbon emissions. Decision makers need to consider the rising number of regulations regarding carbon emissions disclosure.

\section{LIMITATIONS AND SUGGESTIONS}

The limitations of this study are:

1. Only a small number of articles were found using the keywords chosen. The following studies are expected to enlarge the search scope and add more keywords, such as sustainability and SDGs.

2. This research finds that a lot of people are debating whether carbon emissions disclosures are symbolic or substantive in nature. The following studies are expected to focus on management actions regarding this disclosure. 


\section{REFERENCES}

Ascui, F.and Lovell, H. 2011. As frames collide: Making sense of carbon accounting.Accounting, Auditing \& Accountability Journal. Vol. 24. No. 8: 978-999.

Blanco, C., Caro, F.and Corbett C.J. 2017. An Inside Perspective on Carbon Disclosure.Business Horizons. Vol. 60. Issue 5: 635-646.

Bowen, F., Wittneben, B., \& Bowen, F. 2011. Carbon accounting Negotiating accuracy, consistency and certainty across organisational fields. Accounting, Auditing \& Accountability Journal.Vol. 24.No. 8: 1022-1036.

Brohe, A. 2017. The Handbook of Carbon Accounting. A Greenleaf Publishing Book.

Choi, B., Lee, D. and Psaros, J. 2013. An analysis of Australian company carbon emission disclosures.Pacific Accounting Review. Vol. 25. No.1: 58-79.

Caroll, A.B.andBuchholtz, A.K. 1999. Business and society: Ethics and stakeholder management $4^{\text {th }}$ Edition. South Western Publishing: $\mathrm{OH}$, United States.

Deegan, C. 2004. Financial Accounting Theory. Australia: McGraw-Hill Australia Pty Limited

Deegan, C. 2014. Financial Accounting Theory 4th edition. McGraw Hill: Sydney.

El Serafy, S. 1997. Green accounting and economic policy.Ecological Economics. Vol. 21. No. 3: 217-229. 
Eleftheriadis, I.and Evgenia, A. 2017. Measuring the level of corporate commitment regarding climate change strategies. International Journal of Climate Change Strategies and Management. Vol. 9. No. 5: 626-644.

Fink, A. 2010. Conducting Research Literature Review. From the internet to paper, third edition. Sage PublicationInc: Thousand Oaks.

Freeman, R.E. 1984.Strategic management: A stakeholder approach. Boston: Pitman.

Freeman, R.E. et al. 2010. Stakeholder Theory: The State of Art.Cambridge University Press: New York, United States.

Gupta, A.andMaranas, C.D. 2003. Market-based pollution abatement strategies: Risk management using emission option contracts.Industrial \& Engineering Chemistry Research. Vol. 42. No. 4: 802-810.

Gibassier, D., andSchaltegger, S.2015. Carbon management accounting and reporting in practice: a case study on converging emergent approaches. Sustainability Accounting, Management and Policy Journal.Vol. 6. No. 3: 340-365.

Hespenheide, E., Pavlovsky, K., \& McElroy, M. (2010). Accounting for sustainability performance: Organizations that manage and measure sustainability effectively could see benefits to their brand and shareholder engagement and retention as well as to their financial bottom line. Financial Executive 26(2):52-57. 
Haigh, M.and Shapiro, M. 2012. Carbon reporting: does it matter? Accounting, Auditing \& Accountability Journal, Vol. 25. No. 1: 105-125.

Hrasky, S. 2012. Carbon footprints and legitimation strategies: Symbolism or action? Accounting, Auditing \& Accountability Journal. Vol. 25. No. 1: 174-198.

Hurteau, M.D., Koch, G.W.andHungate, B.A. 2008. Carbon protection and fire risk reduction: toward a full accounting of forest carbon offsets.Frontiers in Ecology and the Environment, Vol. 6. No. 9: 493-498.

Jamaludin, NF, Muis, Z and Hashim, H (2019), 'An integrated carbon footprint accounting and sustainability index for palm oil mills', Journal of Cleaner Production, Vol. 225, pp. 496-509.

Kumarasiri, J.andJubb, C. 2016. Carbon emission risks and management accounting: Australian evidence.Accounting Research Journal. Vol. 29. No. 2: 137-153.

KPMG. 2008.Accounting for Carbon: The Impact of Carbon Trading on Financial Statement. URL:

\section{http://www.kpmg.com/BE/Accounting for_Carbon.pdf.}

Accessed on 4 May 2019.

Liddle, B. 2018. Consumption-based accounting and the trade-carbon emissions nexus.Energy Economics. Vol. 69: 71-78.

Lovell, H. and MacKenzie, D. 2011. Accounting for carbon: the role of accounting professional organisations in governing climate change, Antipode. Vol. 43. No. 3: 704-730. 
Maalouf, A.and El-Fadel, M. 2019. Towards improving emissions accounting methods in waste management: A proposed framework.Journal of Cleaner Production. Vol. 206: 197-210.

Marshall, R. and Brown, D. 2003. Corporate environmental reporting: what's in a metric?' Business Strategy and the Environment. Vol. 12: 87-106.

Melo, T. 2012. Determinants of corporate social performance: the influence of organizational culture, management tenure and financial performance. Social Responsibility Journal. Vol. 8. No. 1: 33-47.

Oruc, I.andSarikaya, M. 2011. Normative stakeholder theory in relation to ethics of care.Social Responsibility Journal. Vol. 7. No. 3: 381-392.

Pesqueux, Y.andDamak-Ayadi, S. 2005. Stakeholder theory in perspective. Corporate Governance. Vol. 5. No. 2: 5-21.

Rankin, M., Windsor, C.andWahyuni, D. 2011. An investigation of voluntary corporate greenhouse gas emissions reporting in a market governance system: Australian evidence. Accounting, Auditing \& Accountability Journal. Vol. 24. No. 8: 1037-1070.

Suchman, M. 1995. Managing legitimacy: strategic and institutional approaches. Academy of Management Review. Vol. 20. No. 3: 571-610.

Schmidt, M., and Schmidt, M. 2011. Carbon accounting and carbon footprint - more than just diced results? International Journal of 
Climate Change Strategies and Management. Vol. 1. No. 1: 1930 .

Stechemesser, K. and Guenther, E., 2012. Carbon accounting: a systematic literature review. Journal of Cleaner Production.Vol. 36: 17-38.

Tranfield, D., Denyer, D. and Smart, P., 2003. Towards a methodology for developing evidence-informed management knowledge by means of systematic review. British Journal of Management, 14(3): 207222.

Zvezdov, D. andSchaltegger, S. 2015. Decision Support Through Carbon Management Accounting-A Framework-Based Literature Review. Corporate Carbon and Climate Accounting, Springer Cham: 27-44. 